\title{
Elevated plasma tyrosine kinases VEGF-D and HER4 in heart failure patients decrease after heart transplantation in association with improved haemodynamics
}

\author{
Salaheldin Ahmed ${ }^{1,2} \mathbb{E} \cdot$ Abdulla Ahmed $^{1,2} \mathbb{D} \cdot$ Joanna Säleby ${ }^{1,2} \mathbb{E} \cdot$ Habib Bouzina $^{1,2} \mathbb{( D} \cdot$ Jakob Lundgren $^{1,2} \mathbb{E}$. \\ Göran Rådegran ${ }^{1,2}$ (D)
}

Received: 15 October 2019 / Accepted: 13 December 2019 / Published online: 20 January 2020

(C) The Author(s) 2020

\begin{abstract}
Receptor tyrosine kinases (RTKs) are implicated in cardiovascular growth and remodelling. We aimed to identify the plasma levels of RTKs and related proteins and their association with haemodynamic alterations in heart failure (HF) and related pulmonary hypertension ( $\mathrm{PH}$ ) following heart transplantation (HT). Using proximity extension assay, 28 RTKs and related proteins were analysed in plasma from 20 healthy controls and $26 \mathrm{HF}$ patients before and 1-year after HT. In end-stage HF, out of 28 RTKs, plasma vascular endothelial growth factor-D (VEGF-D) and human epidermal growth factor-4 (HER4) were elevated compared to controls $(p<0.001)$, but decreased $(p<0.0001)$ and normalised after HT. Following HT, plasma changes $(\Delta)$ of VEGF-D correlated with $\Delta$ mean pulmonary artery pressure $\left(r_{\mathrm{s}}=0.65, p=0.00049\right), \Delta$ pulmonary artery wedge pressure $\left(r_{\mathrm{s}}=0.72, p<0.0001\right), \Delta$ pulmonary arterial compliance (PAC) $\left(r_{\mathrm{s}}=-0.52, p=0.0083\right)$ and $\Delta$ pulmonary vascular resistance (PVR) $\left(r_{\mathrm{s}}=0.58, p=0.0032\right) . \Delta$ HER4 correlated with $\Delta$ mean right atrial pressure $\left(r_{\mathrm{s}}=0.51, p=0.012\right)$, $\Delta$ NT-proBNP $\left(r_{\mathrm{s}}=0.48, p=0.016\right)$ and $\Delta$ cardiac index $\left(r_{\mathrm{s}}=-0.56, p=0.0044\right)$. In HF patients following HT, normalisation of VEGF-D reflected reversal of passive pulmonary congestion and restored PAC and PVR; whereas the normalisation of HER4 reflected decreased volume overload and improved cardiac function. The precise function of these proteins, their potential clinical use and pathophysiological relation in HF and related PH remain to be elucidated.
\end{abstract}

Keywords Haemodynamics $\cdot$ Heart failure $\cdot$ Heart transplantation $\cdot$ Pulmonary hypertension $\cdot$ Receptor protein-tyrosine kinases

\section{Introduction}

Heart failure (HF), a global pandemic present in 1-2\% of the adult population, is caused by pathological changes in structural and/or functional properties of the cardiomyocytes,

Electronic supplementary material The online version of this article (https://doi.org/10.1007/s00380-019-01548-1) contains supplementary material, which is available to authorized users.

Salaheldin Ahmed

salaheldin.ahmed@med.lu.se

1 Department of Clinical Sciences Lund, Cardiology, Lund University, Lund, Sweden

2 The Haemodynamic Lab, The Section for Heart Failure and Valvular Disease, VO. Heart and Lung Medicine, Skåne University Hospital, Getingevägen 4, EA15, 22185 Lund, Sweden cardiac interstitium, or both [1, 2]. Apart from pure haemodynamic overload, the progression of HF involves abnormal biochemical signalling of neurohormones, inflammatory cytokines and receptor tyrosine kinases (RTK), culminating into aberrant cardiac vascularisation and maladaptive left ventricular remodelling [2-4].

A frequent complication in HF irrespective of ejection fraction is pulmonary hypertension $(\mathrm{PH})$ impacting negatively on symptoms and outcome. PH due to left heart disease (LHD) is mainly induced by left HF, congenital or valvular heart diseases and if sustained may lead to endothelial dysfunction, followed by excessive vasoconstriction and pulmonary vascular remodelling [5-7]. Moreover, such PH may advance into a "fixed" phenotype, harbouring stiff vessels unresponsive to pulmonary vasodilators, potentially imposing a relative contraindication for heart transplantation (HT) [7-9]. 
In the field of HF, blood borne biomarkers, including proteomics, are an area of immense interest and may in addition to their clinical utility, provide a profound pathophysiological understanding [8,9]. Likewise, the most recent state-of-the-art review of $\mathrm{PH}$ pathology and pathobiology, highlight the importance of future biomarker research in the field of PH [10]. Noteworthy are RTKs and related proteins, involved in signalling pathways of vascular remodelling in $\mathrm{PH}$, such as in pulmonary arterial hypertension (PAH), angiogenesis as well as in cardiac remodelling [10-12]. RTK are also emerging as potential prognostic and/or diagnostic targets in PH [10, 13, 14].

Although the principle aetiology of PH-LHD has been described, the precise underlying pathophysiology remains unclear and whether treatment of the pulmonary vascular component with PAH targeted therapies is beneficial, remains uncertain $[15,16]$. Identifying new proteins related to the reversal of $\mathrm{HF}$ and associated $\mathrm{PH}$ with corresponding haemodynamic improvement may consequently aid in noninvasive and rapid detection of haemodynamic deterioration and in generating new hypotheses for experimental testing and clinical research. This may in turn offer new approaches for optimised treatments of HF and aid in future clinical decision making such as the incorporation of a multi-marker panel of biomarkers for personalisation of care $[9,17]$.

In search for new biomarkers potentially associated with the pathophysiology of $\mathrm{HF}$ and concomitant $\mathrm{PH}$, we aimed to identify the plasma levels of RTKs and related proteins and their association with haemodynamic alterations in $\mathrm{HF}$ and related $\mathrm{PH}$, before vs. after $\mathrm{HT}$.

\section{Material and methods}

\section{Study population}

The present study, including those with PH-LHD, focused on end-stage left HF patients who were haemodynamically evaluated at Skåne University Hospital, Lund, Sweden between October 2011 and February 2016 and who approved to be included in a prospective cohort study and had blood samples collected before and during the 1-year follow-up after HT $(n=29)$. Amongst these, patients with missing postoperative haemodynamic data $(n=2)$ or with persistent PH after HT $(n=1)$ were excluded. Systolic and diastolic left ventricular dysfunction was diagnosed with echocardiography and/or magnetic resonance imaging and HF diagnosis was based on 2016 ESC guidelines [1]. The study also included 20 healthy controls, enrolled between December 2015 and March 2017, with no reported events of myocardial infarction, atrial fibrillation, stroke or diabetes mellitus. All participants were $\geq 18$ years old. The study was conducted in accordance to the declaration of Helsinki and Istanbul. Ethical approval was obtained from the ethical board in Lund, Sweden (diary numbers: 2010/114; 2010/442; 2011/368; 2011/777; 2014/92 and 2015/270). Informed written consents were obtained individually from all participants.

\section{Protein analysis}

Venous blood samples, collected between October 2011 and March 2017 from healthy controls and patients during clinical evaluations of HF during right heart catheterisation (RHC) before and 1-year after HT, were utilised. The samples were stored at $-80{ }^{\circ} \mathrm{C}$ in the Lund Cardio Pulmonary Register (LCPR) cohort of Region Skåne's biobank, initiated 2011. There was no time separation between blood sampling and the haemodynamic assessments before and 1-year after HT.

Plasma levels of NT-proBNP and 28 proteins belonging or related to RTK were analysed with proximity extension assay (PEA), which utilises pairs of protein specific oligonucleotide-linked antibodies and involves qPCR, to detect and quantify target proteins (Proseek Multiplex Cardiovascular II, III and Oncology II kits, Olink Proteomics, Uppsala, Sweden) [18]. All panels are validated regarding sensitivity, dynamic range, specificity, precision (repeatability and reproducibility) and scalability. More information can be found by downloading the panel specific validation data documents, www.olink.com/downloads. The proteins' levels were expressed with linear NPX (Normalised Protein eXpression), a relative quantification scale in arbitrary units.

\section{Proteins}

Plasma proteins were grouped according to receptors and associated ligands into (1) vascular endothelial growth factor (VEGF) family: platelet-derived growth factor subunit (PDGF)-A, PDGF-B, VEGF-A, VEGF-D, VEGF-receptor (VEGFR)-2, VEGFR-3, placenta growth factor (PIGF); (2) epidermal growth factor (EGF) family: amphiregulin, pro-epidermal growth factor (EGF), EGF receptor (EGFR), proheparin-binding EGF-like growth factor (HB-EGF), human epidermal growth factor receptor 2 (HER2), HER3, HER4, transforming growth factor alpha (TGF- $\alpha$ ); (3) TEK family: angiopoietin-1, angiopoietin-1 receptor (Tie-2); (4) TAM receptor kinase (TAM) family: tyrosine-protein kinase Mer (MERTK), tyrosine-protein kinase receptor UFO (AXL); (5) ephrin receptor family: ephrin type-A receptor 2 (EphA2), ephrin type-B receptor 4 (EphB4); (6) intracellular tyrosine kinase family: tyrosine-protein kinase ABL1 (ABL1), tyrosine-protein kinase Lyn (LYN), proto-oncogene tyrosine-protein kinase Src (SRC); (7) other tyrosine kinases: fibroblast growth factor-binding protein 1 (FGF$\mathrm{BP} 1)$, hepatocyte growth factor (HGF), proto-oncogene 
tyrosine-protein kinase receptor Ret (RET) and stem cell factor (SCF).

\section{Haemodynamic assessment}

Haemodynamics were evaluated in patients by RHC in supine position, by inserting a Swan Ganz catheter (Baxter Health Care Corp, Santa Ana, CA) through an introducer predominantly into the right internal jugular vein. Acquired parameters included mean-, systolic- and diastolic pulmonary artery pressures (mPAP, sPAP, dPAP), mean right atrial pressure (MRAP) and pulmonary artery wedge pressure (PAWP). Heart rate (HR) and cardiac output (CO) were obtained by electrocardiography and thermodilution, respectively. Mixed venous oxygen saturation $\left(\mathrm{SvO}_{2}\right)$ was measured from the pulmonary artery and arterial oxygen saturation $\left(\mathrm{SaO}_{2}\right)$ from the radial artery. Arteriovenous oxygen difference a- $\mathrm{vO}_{2}$ diff $=\left(\mathrm{SaO}_{2}-\mathrm{SvO}_{2}\right) \times$ plasma haemoglobin $\times 1.34$. Mean arterial pressure (MAP) was measured noninvasively.

\section{Haemodynamic definitions and renal clearance}

Calculated parameters include cardiac index $(\mathrm{CI})=\mathrm{CO} /$ body surface area (BSA), stroke volume $(\mathrm{SV})=\mathrm{CO} /$ $\mathrm{HR}$, stroke volume index $(\mathrm{SVI})=\mathrm{SV} / \mathrm{BSA}$, transpulmonary pressure gradient $(\mathrm{TPG})=\mathrm{mPAP}-\mathrm{PAWP}$, pulmonary vascular resistance $(\mathrm{PVR})=\mathrm{TPG} / \mathrm{CO}, \mathrm{PVR}$ index $(\mathrm{PVRI})=\mathrm{TPG} / \mathrm{CI}$, diastolic pulmonary pressure gradient $(D P G)=$ dPAP - PAWP, right ventricular stroke work index $($ RVSWI $)=($ mPAP - MRAP $) \times$ SVI, left ventricular stroke work index $($ LVSWI $)=($ MAP - PAWP $) \times$ SVI and pulmonary arterial compliance $(\mathrm{PAC})=\mathrm{SV} /(\mathrm{sPAP}-\mathrm{dPAP})$. The creatinine-based estimation of glomerular filtration rate (eGFR) was calculated using the revised Lund-Malmö formula [19].

PH-LHD was diagnosed by cardiologists, defined according to guidelines as a resting $\mathrm{mPAP} \geq 25 \mathrm{mmHg}$ and a PAWP $>15 \mathrm{mmHg}$. This was further sub-classified into (1) isolated post-capillary $\mathrm{PH}$ (DPG $<7 \mathrm{mmHg}$ and/or PVR $\leq 3$ $\mathrm{WU}$ ) or (2) combined post- and pre-capillary PH (DPG $\geq 7$ and/or PVR $>3 \mathrm{WU}$ ) [5]. HT were performed in accordance with the International Society for Heart Lung Transplantation $[20,21]$. The heart transplantation procedures were performed at Skåne University Hospital, Lund, Sweden.

\section{Patients' characteristics}

Patients' characteristics before and 1-year after HT are shown in Table 1 as previously described [22]. Among the 26 included patients, three (11.5\%) had diabetes mellitus, five (19\%) had hypertension and 14 (54\%) had a history of atrial fibrillation before HT. Haemodynamic characteristics of all patients $(n=26)$ and a subgroup $(n=19)$ with PHLHD are described in Table 2 and Supplementary Table 1, respectively. MPAP, PAWP, MRAP, PVR, PVRI and a-vO $\mathrm{V}_{2}$ diff decreased, whereas MAP, CO, CI, SV, SVI, PAC, LVSWI and $\mathrm{SvO}_{2}$ increased after HT $(p<0.0003)$. Moreover, TPG, DPG, HR and RVSWI did not change before vs. 1 -year after HT (FDR < 0.01). Patients' eGFR did not differ before vs. after HT $(p=0.15)$. In addition, the 20 controls had a median (IQR) age of $41(26.8-50.5)$ years, MAP 89 $(95-100) \mathrm{mmHg}$, BSA $1.92(1.75-1.99) \mathrm{m}^{2}(n=19)$ and 10 $(50 \%)$ were female.

\section{Statistics}

Given the small population and dominance of non-parametric data, Wilcoxon signed-rank test, Mann-Whitney $U$ test and Spearman's rank correlation were used as appropriate. Values are presented as median [interquartile range (IQR)], unless otherwise stated. The two-stage step-up procedure of false discovery rate (FDR) was used to adjust for mass significance [23]. Two-sided $p$ values lower than FDR thresholds were considered statistically significant. Statistical analyses were performed using Prism version 8.01 for Windows, GraphPad Software, La Jolla California USA, www.graphpad.com).

\section{Study setup}

Three protein level specific comparisons were made, control vs. pre-HT, control vs. post-HT and post-HT vs. pre-HT. To select relevant proteins related to the reversal of HF and $\mathrm{PH}$, three inclusion criteria were set: (1) a significant difference between post-HT vs. pre-HT, (2) a significant difference between control vs. pre-HT, as well as (3) a level change resembling a normalisation pattern towards controls' levels after HT (FDR < 0.01). Proteins meeting all inclusion criteria were tested for correlation with NT-proBNP and haemodynamic parameters reflecting pulmonary passive congestion as well as right and left sided cardiac parameters, i.e. mPAP, PAC, PAWP, PVR, MRAP, CI and LVSWI (FDR $<0.1$ ). Proteins meeting all three criteria and reflecting haemodynamic alterations were of specific interest. Next, specific correlations within the pre-HT group between proteins' levels and haemodynamics were made. The study setup is summarised in (Fig. 1).

\section{Results}

\section{Protein selection}

The proteins' baseline values and plasma alterations following HT are presented in Table 3. Out of 28 RTKs, nine 
Table 1 Characteristics of patients before and 1-year after heart transplantation

\begin{tabular}{|c|c|c|c|c|}
\hline \multirow[t]{2}{*}{ Variable } & \multicolumn{2}{|c|}{ Pre-HT $(n=26)$} & \multicolumn{2}{|c|}{ Post-HT $(n=26)$} \\
\hline & $n$ & Median (IQR) & $n$ & Median (IQR) \\
\hline Female $n(\%)$ & $5(19.2)$ & & & \\
\hline Age (years) & 26 & $50(45-61)^{\mathrm{a}}$ & 26 & $52(47-63)$ \\
\hline Height $(\mathrm{cm})$ & 26 & $178(172-180)$ & 26 & $177(172-181)$ \\
\hline Weight (kg) & 25 & $80(71-89)$ & 26 & $78(69-90)$ \\
\hline $\operatorname{BSA}\left(\mathrm{m}^{2}\right)$ & 25 & $2(1.8-2.1)$ & 26 & $2(1.8-2.1)$ \\
\hline Creatinine $(\mu \mathrm{mol} / \mathrm{L})$ & 25 & $108(90-123)$ & 26 & $114(97-142)^{\mathrm{b}}$ \\
\hline eGFR $\left(\mathrm{mL} / \mathrm{min} / 1.73 \mathrm{~m}^{2}\right)$ & 25 & $63(55-71)$ & 26 & $53(43-72)^{\mathrm{b}}$ \\
\hline Atrial fibrillation $n(\%)$ & 26 & $13(50)$ & 26 & - \\
\hline Hypertension $n(\%)$ & 26 & $5(19.2)$ & 26 & $3(11.5)$ \\
\hline \multirow[t]{2}{*}{ Diabetes mellitus $n(\%)$} & 26 & $1(3.8)$ & 26 & $9(34.6)$ \\
\hline & & $n(\%)$ & & $n(\%)$ \\
\hline \multicolumn{5}{|l|}{$\mathrm{HF}$ and $\mathrm{PH}$ classification } \\
\hline HFrEF & & $24(92.3)$ & & - \\
\hline HFpEF & & $2(7.7)$ & & - \\
\hline $\mathrm{PH}$ & & $19(73.1)^{\mathrm{c}}$ & & - \\
\hline IpC-PH & & $10(38.5)$ & & - \\
\hline $\mathrm{CpC-PH}$ & & $9(34.6)$ & & - \\
\hline \multicolumn{5}{|l|}{ HF aetiology } \\
\hline DCM & & $17(65.4)$ & & - \\
\hline $\mathrm{HCM}$ & & $3(11.5)$ & & - \\
\hline ICM & & $3(11.5)$ & & - \\
\hline Other & & $3(11.5)$ & & - \\
\hline \multicolumn{5}{|l|}{ Medications } \\
\hline$\beta$-blockers & & $25(96.2)$ & & $9(34.6)$ \\
\hline ACEi & & $11(42.3)$ & & - \\
\hline ARB & & $11(42.3)$ & & $10(38.5)$ \\
\hline MRA & & $22(84.6)$ & & $3(11.5)$ \\
\hline Furosemide & & $24(92.3)$ & & $12(46.2)$ \\
\hline Cordarone & & $4(15.4)$ & & - \\
\hline Prednisolone & & $1(3.8)$ & & $25(96.2)$ \\
\hline Cyclosporine & & - & & $3(11.5)$ \\
\hline Tacrolimus & & - & & $23(88.5)$ \\
\hline Mycophenolate mofetil & & - & & $21(80.8)$ \\
\hline Azathioprine & & - & & $5(19.2)$ \\
\hline
\end{tabular}

$H T$ heart transplantation, IQR interquartile range, $B S A$ body surface area $=\left(\right.$ weight $^{0.425} \times$ height $\left.^{0.725}\right) \times 0.007184$ [55], $P H$ pulmonary hypertension, $H F r E F$ and $H F p E F$ heart failure with reduced $(\mathrm{EF}<50 \%)$ and preserved ejection fraction $(\mathrm{EF} \geq 50 \%), I p C-P H$ isolated post-capillary $\mathrm{PH}$, $C p C$ - $P H$ combined post and pre-capillary $\mathrm{PH}, D C M$ dilated cardiomyopathy, $H C M$ hypertrophic $\mathrm{CM}, I C M$ ischemic CM, $A C E i$ angiotensin converting enzyme inhibitor, $A R B$ angiotensin receptor blocker, $M R A$ mineralocorticoid receptor antagonist

${ }^{\mathrm{a}} p<0.0001$, FDR $<0.01$; vs. control

${ }^{b}$ Nonsignificant vs. Pre-HT

${ }^{\mathrm{c}}$ One patient could not complete the right heart catheterisation due to severe orthopnea. After optimisation with furosemide and levosimendan, subsequent right heart catheterisation confirmed IpC-PH

proteins met all three inclusion criteria (Fig. 1), of which VEGF-D and HER4 were associated with the largest number of haemodynamic parameters.

\section{Plasma VEGF-D and HER4 in end-stage heart failure patients}

In end-stage HF patients with or without $\mathrm{PH}$, the plasma levels of VEGF-D (Fig. 2) and HER4 (Fig. 3) were elevated in 


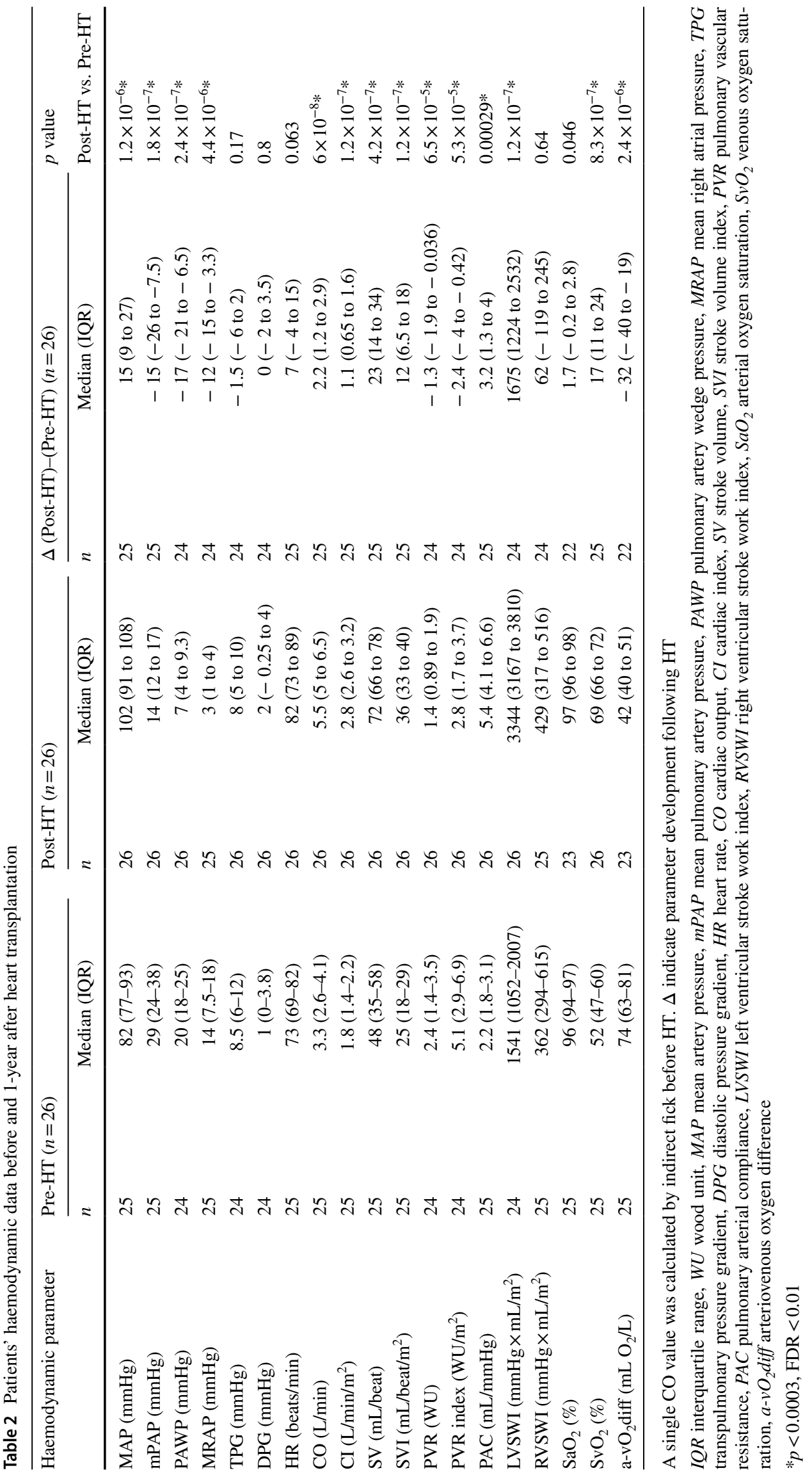


Fig. 1 Selection of proteins corresponding to the reversal of heart failure and related pulmonary hypertension. $R T K$ receptor tyrosine kinases, $H F$ heart failure, $P H$ pulmonary hypertension. Proteins' abbreviations as in Table 2. False discovery rate (FDR) was used to accommodate for mass significance, (criterion I-III, FDR $<0.01$ ); (correlation analysis, FDR $<0.1$ )

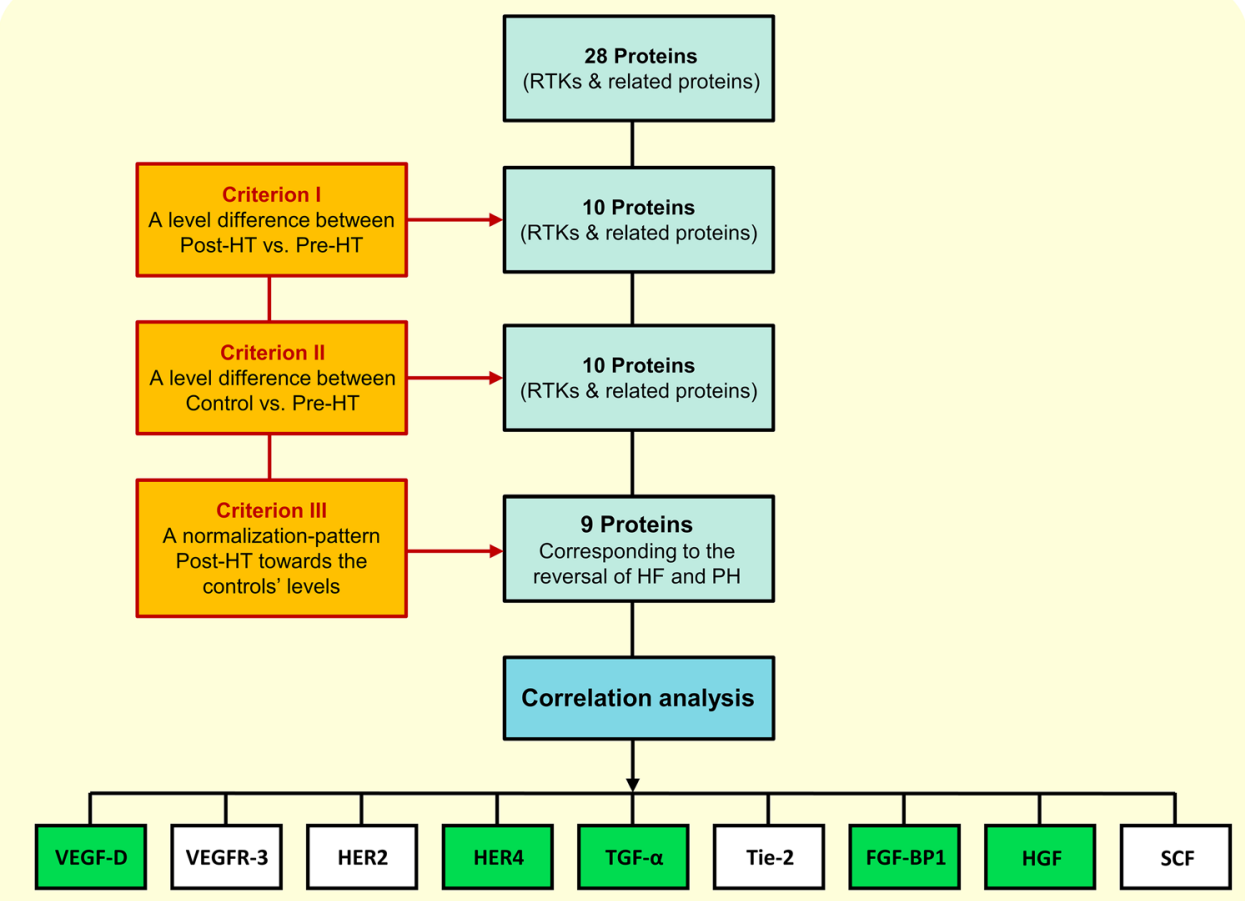

Correlated with improved clinical parameters after HT comparison to controls $(p<0.001, \mathrm{FDR}<0.01)$. In response to $\mathrm{HT}$, resolving pre-existing $\mathrm{HF}$, these levels decreased $(p<0.0001$, FDR $<0.01)$ and normalised, matching controls' levels (Table 3).

\section{Plasma VEGF-D and HER4 level changes correlate with haemodynamic alterations}

Spearman's correlation coefficients and corresponding $p$ values of associations between changes $(\Delta)$ in proteins' levels with $\Delta$ NT-proBNP and $\Delta$ haemodynamic parameters following HT are illustrated in Table 4. $\triangle$ VEGF-D (Fig. 2) correlated with $\triangle \mathrm{mPAP}, \triangle \mathrm{PAWP}, \triangle \mathrm{PAC}$ and $\triangle \mathrm{PVR}$ $(p<0.01$; FDR $<0.1)$; whereas $\triangle$ HER4 (Fig. 3$)$ correlated with $\triangle$ NT-proBNP, $\triangle$ MRAP and $\Delta \mathrm{CI}(p<0.02$; FDR $<0.1)$. Baseline correlations of VEGF-D and HER4 with haemodynamic parameters before HT are described in Supplementary Table 2.

\section{Other RTKs and related proteins in end-stage heart failure patients}

The plasma levels of VEGFR-3, HER2, TGF- $\alpha$, Tie-2, HGF and FGF-BP1 were elevated in patients with severe $\mathrm{HF}$ with or without $\mathrm{PH}$, compared to healthy controls $(p<0.01$, FDR $<0.01)$. In response to $\mathrm{HT}$, resolving $\mathrm{HF}$ and $\mathrm{PH}$, these levels decreased $(p<0.01, \mathrm{FDR}<0.01)$ towards controls' levels. Plasma SCF were, however, low in HF patients in comparison to healthy controls $(p<0.0001$, FDR $<0.01)$. These levels increased after HT $(p<0.01)$, matching the controls' levels (Table 3 ). These seven proteins correlated either with few clinical parameters or none as described in Table 4. Baseline correlations between proteins and selected haemodynamic parameters before HT are described in Supplementary Table 2 .

\section{Discussion}

RTK signalling regulates diverse cellular functions through activation of the downstream mitogen-activated protein kinases, of which ERK1/2, ERK5 and JNK are pivotal in cardiac development, hypertrophy as well as in both physiological and pathophysiologic cardiac remodelling [3]. In the present study, among the 28 RTKs and related proteins, plasma VEGF-D and HER4 were elevated in severe HF patients compared to controls. The elevated plasma VEGFD and HER4 normalised after HT, matching controls' levels. The decrease of plasma VEGF-D after HT furthermore reflected reversed passive pulmonary congestion and possibly pulmonary vasoconstriction, with the latter indicated by correlations with PAC and PVR. Moreover, decreased HER4 after HT was associated with improved cardiac function and decreased volume overload. Identifying the precise functional roles of VEGF-D and HER4, as well as their clinical implications may be of great importance as these proteins 


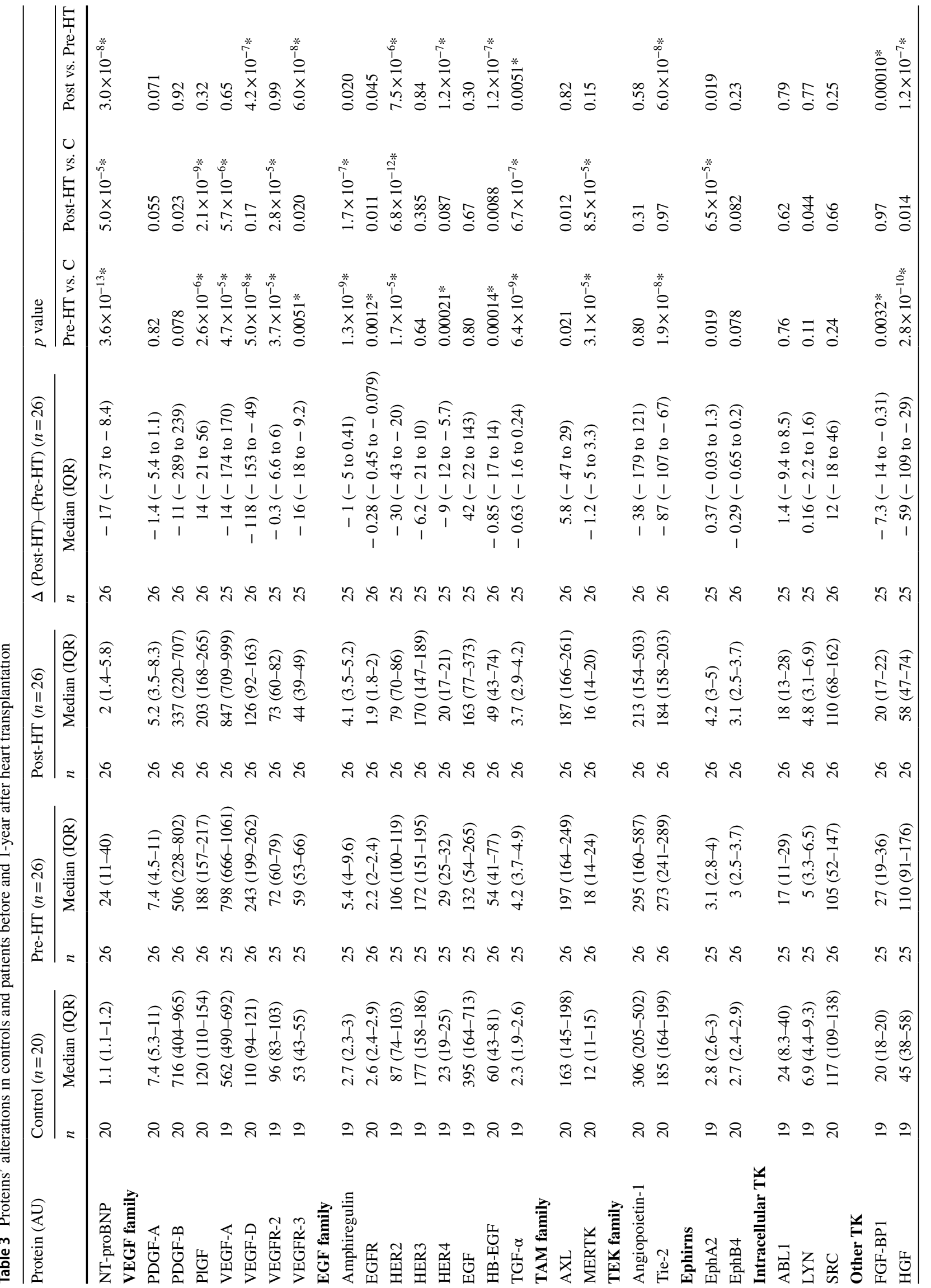




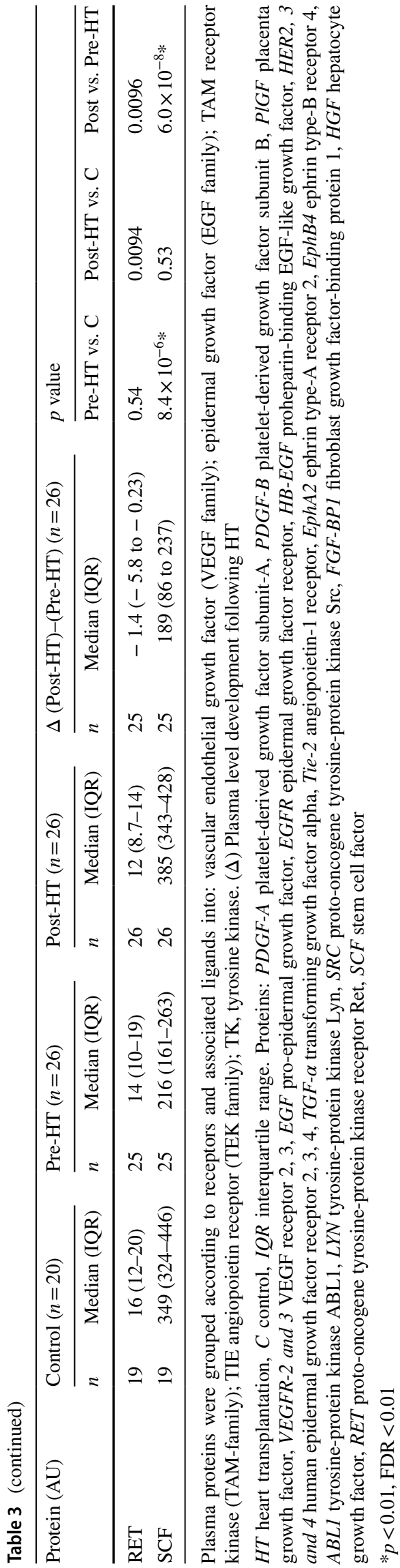

may be utilised as potential biomarkers, with possible pathophysiological importance, in HF and related $\mathrm{PH}$.

VEGF-D is known to be a potent mediator involved in lymph and regular angiogenesis, endothelial proliferation as well as vascular and cardiac remodelling, through VEGFR-3 and/or VEGFR-2 binding [24, 25]. It is expressed by a variety of tissues, most abundantly in heart, lungs and skeletal muscles [26]. VEGFR-3 is expressed in endothelial cells and crucial for primary vascular network maturation and early cardiovascular system development [27]. In a mouse model of chronic airway inflammation, elevated VEGF-D expression induced lymphatic sprouting and increased lymphatic drainage [28]. In the clinical field, plasma VEGF-D is furthermore a diagnostic and a severity marker of lymphangioleiomyomatosis [29].

Dyspnoea and pulmonary extravascular fluid accumulation are common, non-specific features in HF, particularly in PH-LHD due to backward transmission of elevated left sided filling pressures, increasing PAWP and mPAP $[6,30,31]$. In a clinical study of dyspnoeic patients, plasma VEGF-D correlated with NT-proBNP and elevated levels were most abundantly found in HF diagnosed patients. Accordingly, the authors hypothesised that the elevated plasma VEGF-D may be a marker of HF and pulmonary congestion, where VEGF-D upregulation may be involved in pulmonary vascular and/or cardiac remodelling [30]. Likewise, in a recent study, plasma VEGF-D correlated with PAWP and its elevation in HF patients was hypothesised to augment pulmonary lymphatic clearance and mitigate the symptoms of pulmonary congestion [32]. Interestingly, we found that plasma VEGFR-3 levels changed similarly to VEGF-D, which theoretically may reflect increased VEGF-D mediated signalling, thereby increased pulmonary lymphangiogenesis and lymphatic clearance, mitigating potential symptoms of pulmonary congestion. In the present study, we provide additional evidence that elevated plasma of VEGF-D levels in end-stage HF normalise along with the haemodynamics in response to HT. Furthermore, the decrease in plasma VEGF$\mathrm{D}$ after HT correlated with $\triangle \mathrm{mPAP}, \triangle \mathrm{PAWP}, \triangle \mathrm{PVR}$ and $\triangle \mathrm{PAC}$, indicating a decrease in passive pulmonary congestion and potentially, if existent, reversal of PAC and PVR towards a restored pulmonary vascular state. Therefore, VEGF-D may have the potential to be used as a biomarker to assess the haemodynamic strain and/or the severity of HF and PH-LHD as well as in the differentiation between isolated post and combined post and pre-capillary $\mathrm{PH}$, as it correlated with mPAP, PAWP and PVR.

Furthermore, VEGF-mediated VEGFR-2 activation stimulates cardiomyocyte growth [33] and intramyocardially administrated VEGF-D facilitates therapeutic cardiac angiogenesis, increasing myocardial perfusion in patients with refractory angina [34]. Additionally, a meta-analysis showed that treatment with approved multiple tyrosine 
(a)

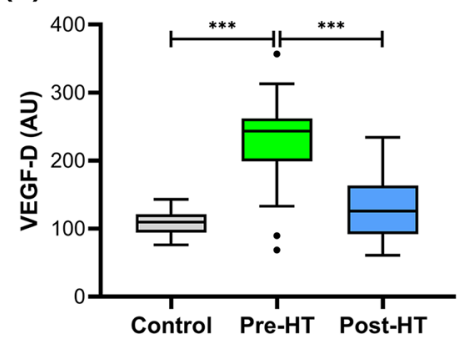

(d)

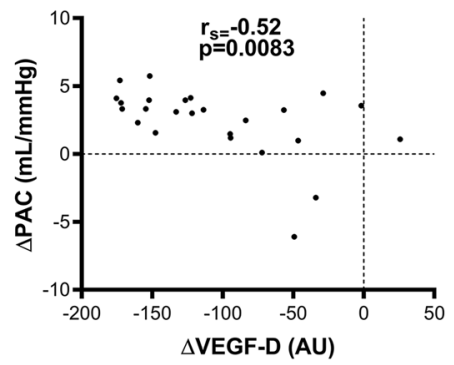

(b)

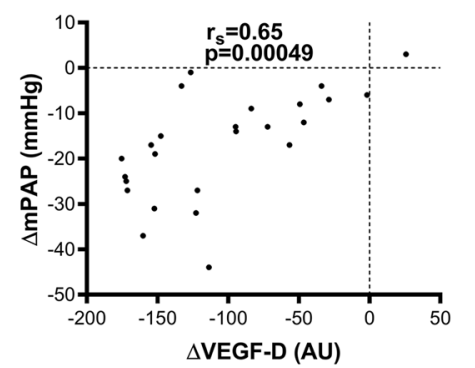

(e)

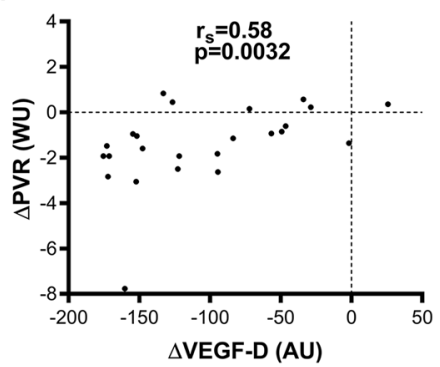

(c)

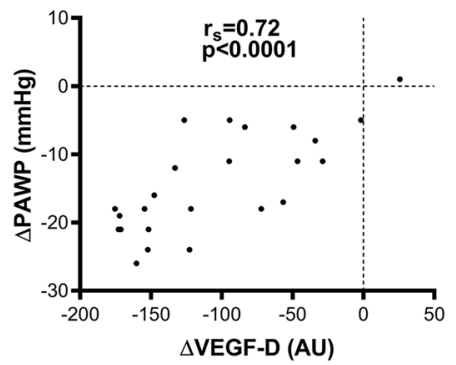

Fig. 2 Plasma VEGF-D and correlations with haemodynamic changes following heart transplantation. Outliers calculated with Tukey's fence. $H T$ heart transplantation, $A U$ arbitrary units, $r_{s}$ Spearman's correlation coefficient; $* * * p<0.0001$. Haemodynamic abbreviations as in Table 2. a VEGF-D levels in controls and heart failure patients before and 1-year after HT. The decrease $(\Delta)$ of VEGF-D post-HT correlated with b $\triangle \mathrm{mPAP}, \mathbf{c} \triangle \mathrm{PAWP}, \mathbf{d} \triangle \mathrm{PAC}$ and $\mathbf{e} \mathrm{PVR}$
Fig. 3 Plasma HER4 and correlations with haemodynamic changes following heart transplantation. Outliers calculated with Tukey's fence. $H T$ heart transplantation, $A U$ arbitrary units, $r_{s}$ Spearman's correlation coefficient; $* * p<0.001$ $* * * p<0.0001$. Haemodynamic abbreviations as in Table 2. a HER4 levels in controls and heart failure patients before and 1-year after HT. The decrease $(\Delta)$ of HER4 post-HT correlated with b $\triangle$ NT-proBNP, $\mathbf{c}$ $\triangle$ MRAP and $\mathbf{d}$ improved $\mathrm{CI}$ (a)

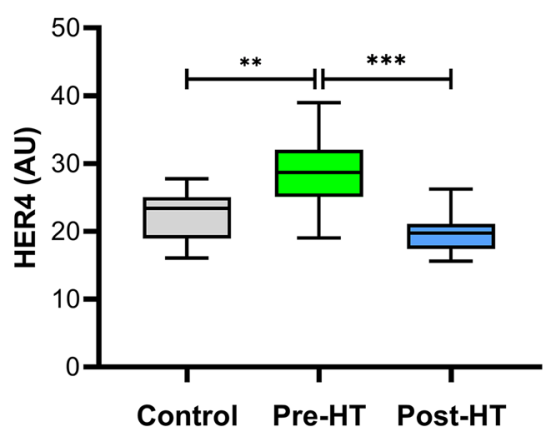

(c)

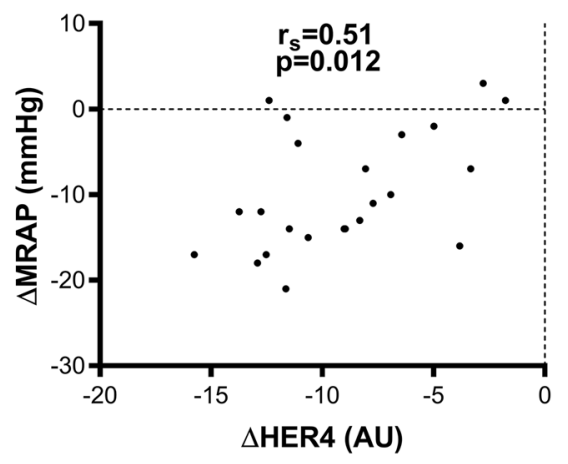

(b)

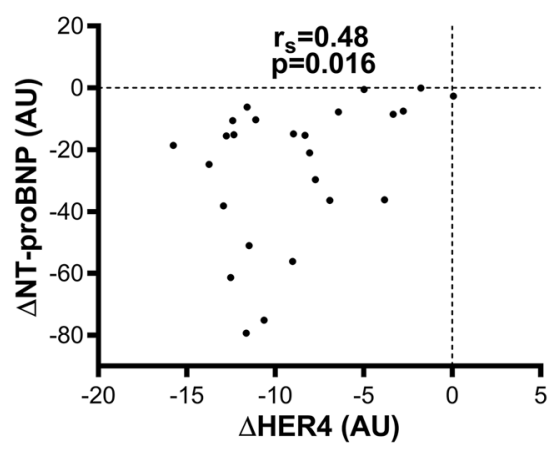

(d)

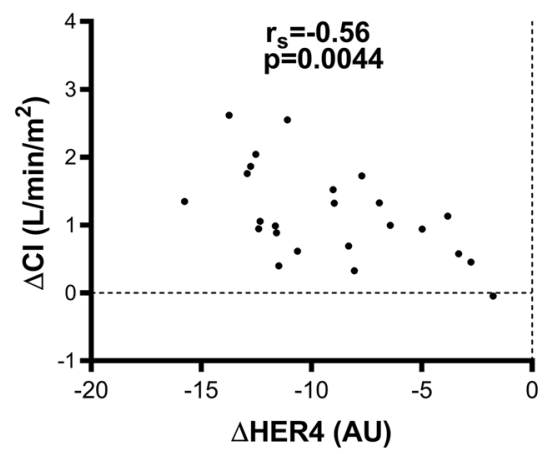

kinase inhibitors was associated with higher risk of congestive heart failure compared to non-tyrosine kinase treated
[35]. In the present study, however, the plasma levels of VEGFR-2 did not change before vs. after HT and remained 


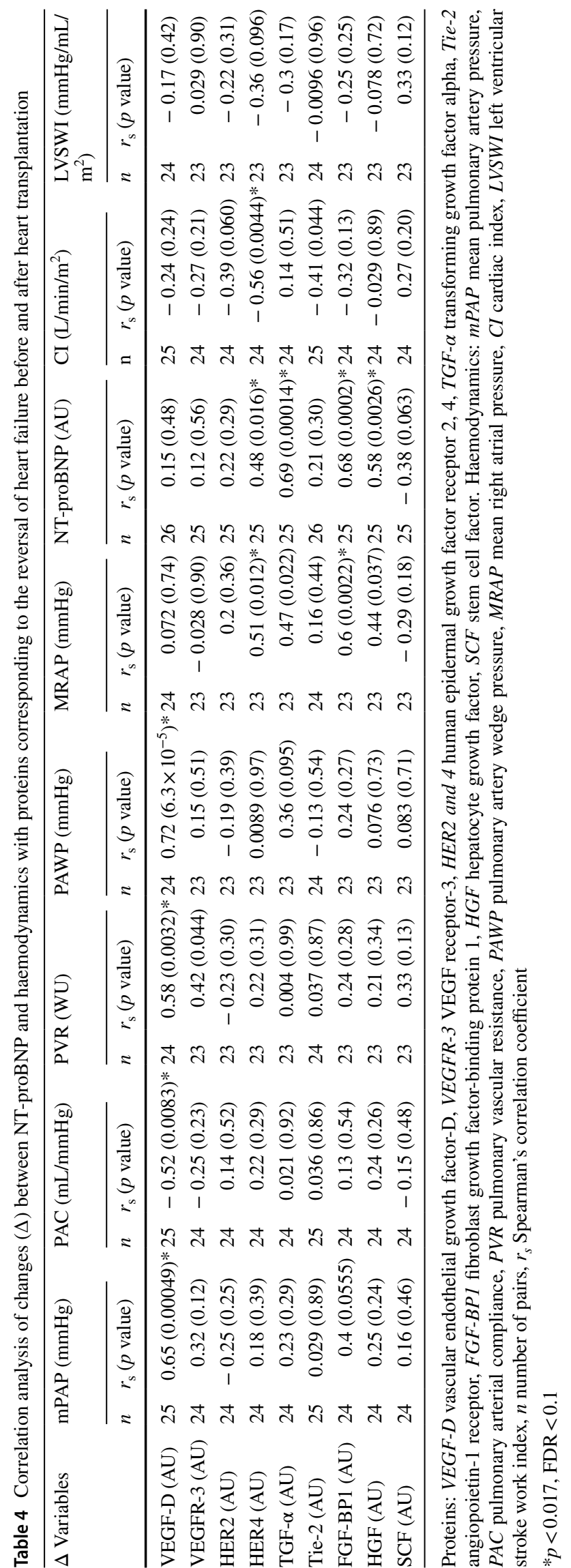

low compared to healthy controls. Thus, it remains uncertain whether VEGF-D mediated VEGFR-2 signalling impacts cardiac remodelling and/or facilitates favourable cardiac angiogenesis during $\mathrm{HF}$.

PH-LHD may ultimately lead to pulmonary vascular remodelling [6], which may be similar to, but not precisely the same as that observed in PAH patients $[15,36]$. In the context of in vivo research, a model of severe angio-obliterative PAH displayed that expressions of VEGF-D and VEGFR-3 were elevated in lung tissue and inhibition of VEGFR-3 signalling prevented angio-obliteration, but did not reverse already existing vascular remodelling [37]. In clinical studies, high plasma VEGF-D differentiated PHLHD from PAH, chronic thromboembolic PH (CTEPH) and controls, and a similar increase was related to PAH progression in systemic sclerosis patients [13, 14]. Further, we have recently confirmed in a larger patient cohort that apart from the levels being highest in HF patients with reduced ejection fraction with PH, plasma VEGF-D elevations were also found in PAH and CTEPH patients compared to healthy controls [38]. Hence, it is reasonable to hypothesise that VEGF-D and involved signalling pathways may have a role in the reversibility of PVR and PAC in HF patients with or without related PH. Noteworthy is, however, that the correlations between plasma VEGF-D with PAC and PVR may be explained by decongestion. The inverse hyperbolic PVRPAC relationship is sensitive to acute and chronic PAWP elevations, which decrease PAC at a given PVR. This PAWP increase results in augmented total right ventricular pulsatile load, proposedly through enhancing pulmonary arterial pulse reflection, thereby increasing SPAP [39]. Collectively, whether VEGF-D elevation is a compensatory mechanism to ameliorate extravascular fluid accumulation or directly mediate a beneficial or pathological progression of PVR, PAC (independent of LV filling pressures) and/or vascular remodelling secondary to sustained pulmonary and cardiac congestion in $\mathrm{HF}$ and $\mathrm{PH}$ remain to be investigated. Moreover, VEGF-D may be of prognostic utility and aid in risk stratification of HF patients with passive pulmonary congestion, as PAC was proposed as a novel parameter in separating PH due to left HF patients at higher risk of death [40] and a strong predictor of mortality in HF with preserved ejection fraction [41] (Fig. 4).

HER4 signalling is pivotal in myocardial development, ventricular growth, proliferation and functional homeostasis of the adult heart and together with HER2 and their ligand Neuregulin-1 exert protective roles in the myocardium, e.g. enhancing cardiac repair mechanisms, reduce infarctioninduced apoptosis and improve left ventricular ejection fraction [42]. Consequently, Neuregulin-1/HER2/HER4 signalling axis has recently emerged as a novel target to treat congestive $\mathrm{HF}$ and a current clinical trial is determining the efficacy of Neuregulin-1 administration (ClinicalTrials. 

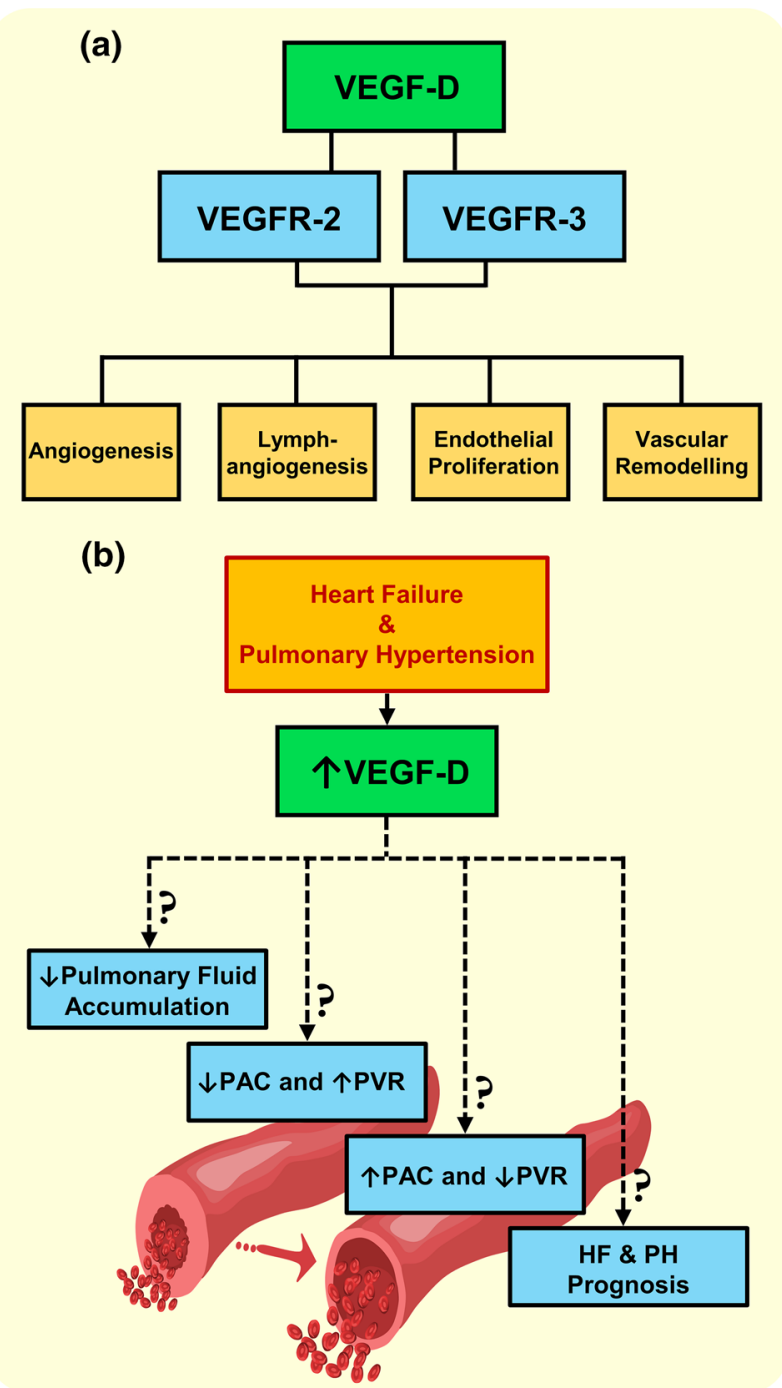

Fig. 4 Illustration of vascular endothelial growth factor-D physiological roles and hypotheses. a Based on previous reports, the effects of VEGF-D mediated signalling through binding to its receptors. b Hypothetical roles and the possible clinical applicability of elevated plasma VEGF-D in heart failure (HF) and related pulmonary hypertension (PH). PAC pulmonary arterial compliance, $P V R$ pulmonary vascular resistance

gov, identifier NCT03388593). Herein, we demonstrate that plasma levels of HER2 and HER4 were high in severe HF compared to controls. These levels decreased postHT, matching controls' levels. Furthermore, the decrease in HER4 levels after HT correlated with $\triangle$ NT-proBNP, $\triangle$ MRAP and increased CI, reflecting reduced cardiac volume overload as well as improved cardiac function. In contrast to our results, another study showed that HER2 and HER4 tissue expressions are suppressed in the myocardium of HF patients in comparison to hearts from healthy controls [43]. This inconsistency can be explained by the fact that circulating receptors do not necessarily reflect a tissue-specific production, as the high plasma concentration in our study may originate from other tissues. Hypothetically, plasma elevation of HER2 and HER4 in response to HF and related haemodynamic worsening may slow HF progression by potentiating Neuregulin-1 effects. To note, however, receptors in plasma may operate differently than the membrane bound receptors and may exert antagonistic effects [44].

Other proteins, which either correlated with few clinical parameters or none, are FGF-BP1, TGF- $\alpha$, HGF, SCF and Tie-2. These, in addition to the aforementioned proteins, may collectively be beneficial or related to the pathophysiological processes of HF. Noteworthy, SCF levels were low before HT, following an increase after HT towards controls' levels. This may support that low plasma levels of SCF are associated with increased cardiovascular disease and mortality [45].

Limitations of our study include a small population and slightly younger controls. However, our study size corresponds to other HT studies, which has resulted in larger trials. A major strength is the use of PEA to assess plasma proteins' levels. This method is highly sensitive, specific and avoids unspecific binding. Even if isoform specific detection of VEGF-D was absent, PEA is superior to traditional multiplex immunoassays [18]. False positive results may, however, be present due to the large number of statistical tests conducted despite adjusting for mass significance. Also, confounding factors such as medication intake, diurnal variations and other comorbidities may have influenced our results. The effects of postoperative withdrawal of HF medications (ACE-inhibitors, $\beta$-blockers and mineral corticoid receptor antagonists) on plasma proteins' levels are unknown. However, it is established that ACE-inhibitors reduce ventricular wall stress and increase $\mathrm{CO}$, whereas $\beta$-blockers enhance left ventricular geometry and function $[46,47]$. Given that RTK signalling is involved in cardiac remodelling and hypertrophy [3], the use of ACE-inhibitors and $\beta$-blockers may thus have affected the proteins' levels. Also, baseline VEGF-D levels correlated with mPAP, PAWP, PAC and PVR, which slightly allow to avoid the post-HT medication limitation. However, this is not apparent for HER4, as its baseline values only correlated with NT-proBNP and MRAP (Supplementary Table 2). Moreover, the use of angiotensin receptor blockers was almost equally distributed between the pre and post-HT groups, and therefore may not have affected our results. Although Everolimus and Sirolimus, (mTOR inhibitors) were not used in our cohort, these are known to inhibit angiogenesis, VEGF-D, VEGF-A and potentially VEGFR [48-51]. Tacrolimus inhibits VEGF, Angiopoietin-1 and Tie-2 [52]. Cyclosporine inhibits VEGF-mediated endothelial migration and angiogenesis [53]. Even though the role of steroids and cell cycle inhibitors remains unknown on plasma proteins' levels, Mycophenolate mofetil has been proposed 
to downregulate downstream HER2 signalling pathways AKT, ERK and JAK-STAT3 [54]. Renal clearance, however, may only have had a minimal role in altering the proteins' plasma concentrations in the transplant patients, as eGFR was unaltered following HT. Moreover, the present correlations between proteins and haemodynamics do not necessarily imply a causal relationship and should thus be interpreted with caution. Nevertheless, the present study is hypothesis generating and our findings may be of interest in developing a multi-marker panel for optimal future management of $\mathrm{HF}$ and related $\mathrm{PH}$.

In conclusion, in HF patients, the decrease and normalisation of the elevated plasma VEGF-D after HT correlated with $\triangle \mathrm{mPAP}, \triangle \mathrm{PAWP}, \triangle \mathrm{PVR}$ and $\triangle \mathrm{PAC}$, indicating VEGF$\mathrm{D}$ to be a potential biomarker of reversed pulmonary passive congestion and possibly restored pulmonary vascular milieu. Moreover, the decrease of elevated plasma HER4 in HF patients correlated with $\triangle \mathrm{NT}$-proBNP, $\triangle \mathrm{MRAP}$ and $\Delta \mathrm{CI}$, reflecting reduced cardiac volume overload and improved cardiac function in response to HT. Altogether, we encourage further research to elaborate the precise roles of these proteins and their clinical implications in HF and related $\mathrm{PH}$ as potential biomarkers of haemodynamic strain and/ or HF/PH-LHD severity, for optimal clinical management of HF patients as well as better understanding of processes underlying the pathophysiology of HF.

Acknowledgements Open access funding provided by Lund University. We acknowledge the support of the Hemodynamic Laboratory staff, The Section for Heart Failure and Valvular Disease, Skåne University Hospital, Lund, Sweden; and The Section for Cardiology, the Department of Clinical Sciences, Lund University, Lund, Sweden. Exceptional gratitude to Anneli Ahlqvist for her efforts in LCPR administration and blood sample management. We also acknowledge the biobank services for their retrieval of blood samples from LCPR performed at Labmedicine Skåne, University and Regional Laboratories, Region Skåne, Sweden.

Funding The work was supported by unrestricted research Grants from Avtal om Läkarutbildning och Forskning (ALF) and Actelion Pharmaceuticals Sweden AB. The funding organisations played no role in the collection, analysis or interpretation of the data and had no right to restrict the publishing of the manuscript.

\section{Compliance with ethical standards}

Conflict of interest Mr. Salaheldin Ahmed and Mr. Abdulla Ahmed report no conflicts of interest. Dr. Säleby reports an unrestricted research grant from The Swedish Society of Pulmonary Hypertension on behalf of GlaxoSmithKline. Mr. Bouzina reports an unrestricted research grant from The Swedish Society of Pulmonary Hypertension on behalf of GlaxoSmithKline. Dr. Lundgren reports unrestricted research grants from The Swedish Society of Pulmonary Hypertension on behalf of Actelion Pharmaceuticals Sweden AB. Dr. Rådegran reports unrestricted research grants from ALF and Actelion Pharmaceuticals Sweden AB, during the conduct of the study. Mr. Abdulla Ahmed and Mr. Salaheldin Ahmed report no personal lecture fees. Dr. Säleby reports personal lecture fees from Actelion Pharmaceuticals Sweden
$\mathrm{AB}$ outside the submitted work. Mr. Bouzina reports personal lecture fees from Actelion Pharmaceuticals Sweden AB outside the submitted work. Dr. Lundgren reports personal lecture fees from Actelion Pharmaceuticals Sweden AB and GlaxoSmithKline outside the submitted work. Dr. Rådegran reports personal lecture fees from Actelion Pharmaceuticals Sweden AB, GlaxoSmithKline, Nordic Infucare and Bayer Health Care outside the submitted work. Dr. Rådegran is, and has been, primary or coinvestigator in clinical PAH trials for GlaxoSmithKline, Actelion Pharmaceuticals Sweden AB, Pfizer, Bayer and United Therapeutics and in clinical heart transplantation immunosuppression trials for Novartis. The companies had no role in the data collection, analysis and interpretation and had no right in disapproving of the manuscript.

Open Access This article is licensed under a Creative Commons Attribution 4.0 International License, which permits use, sharing, adaptation, distribution and reproduction in any medium or format, as long as you give appropriate credit to the original author(s) and the source, provide a link to the Creative Commons licence, and indicate if changes were made. The images or other third party material in this article are included in the article's Creative Commons licence, unless indicated otherwise in a credit line to the material. If material is not included in the article's Creative Commons licence and your intended use is not permitted by statutory regulation or exceeds the permitted use, you will need to obtain permission directly from the copyright holder. To view a copy of this licence, visit http://creativecommons.org/licenses/by/4.0/.

\section{References}

1. Ponikowski P, Voors AA, Anker SD, Bueno H, Cleland JGF, Coats AJS, Falk V, González-Juanatey JR, Harjola VP, Jankowska EA, Jessup M, Linde C, Nihoyannopoulos P, Parissis JT, Pieske B, Riley JP, Rosano GMC, Ruilope LM, Ruschitzka F, Rutten FH, van der Meer P, ESC Scientific Document Group (2016) 2016 ESC Guidelines for the diagnosis and treatment of acute and chronic heart failure: the Task Force for the diagnosis and treatment of acute and chronic heart failure of the European Society of Cardiology (ESC)Developed with the special contribution of the Heart Failure Association (HFA) of the ESC. Eur Heart J 37:2129-2200

2. Braunwald E (2008) Biomarkers in heart failure. N Engl J Med 358:2148-2159

3. Rose BA, Force T, Wang Y (2010) Mitogen-activated protein kinase signaling in the heart: angels versus demons in a heartbreaking tale. Physiol Rev 90:1507-1546

4. Gogiraju R, Bochenek ML, Schäfer K (2019) Angiogenic endothelial cell signaling in cardiac hypertrophy and heart failure. Front Cardiovasc Med 6:20

5. Galiè N, Humbert M, Vachiery JL, Gibbs S, Lang I, Torbicki A, Simonneau G, Peacock A, Vonk Noordegraaf A, Beghetti M, Ghofrani A, Gomez Sanchez MA, Hansmann G, Klepetko W, Lancellotti P, Matucci M, McDonagh T, Pierard LA, Trindade PT, Zompatori M, Hoeper M, ESC Scientific Document Group (2016) 2015 ESC/ERS Guidelines for the diagnosis and treatment of pulmonary hypertension: the Joint Task Force for the Diagnosis and Treatment of Pulmonary Hypertension of the European Society of Cardiology (ESC) and the European Respiratory Society (ERS): Endorsed by: Association for European Paediatric and Congenital Cardiology (AEPC), International Society for Heart and Lung Transplantation (ISHLT). Eur Heart J 37:67-119

6. Rosenkranz S, Gibbs JSR, Wachter R, De Marco T, Vonk-Noordegraaf A, Vachiéry JL (2016) Left ventricular heart failure and pulmonary hypertension. Eur Heart J 37:942-954 
7. Cheli M, Vachiery JL (2015) Controversies in pulmonary hypertension due to left heart disease. F1000Prime Rep 7:7

8. Ibrahim NE, Januzzi JL Jr (2018) Established and emerging roles of biomarkers in heart failure. Circ Res 123:614-629

9. Lund LH, Gabrielsen A (2014) Biomarkers in advanced heart failure-pathophysiology leading to clinical use? J Heart Lung Transplant 33:1213-1214

10. Humbert M, Guignabert C, Bonnet S, Dorfmüller P, Klinger JR, Nicolls MR, Olschewski AJ, Pullamsetti SS, Schermuly RT, Stenmark KR, Rabinovitch M (2019) Pathology and pathobiology of pulmonary hypertension: state of the art and research perspectives. Eur Respir J 53:1801887

11. Koch S, Claesson-Welsh L (2012) Signal transduction by vascular endothelial growth factor receptors. Cold Spring Harb Perspect Med 2:a006502

12. Bersell K, Arab S, Haring B, Kühn B (2009) Neuregulin1/ErbB4 signaling induces cardiomyocyte proliferation and repair of heart injury. Cell 138:257-270

13. Kylhammar D, Hesselstrand R, Nielsen S, Scheele C, Rådegran G (2018) Angiogenic and inflammatory biomarkers for screening and follow-up in patients with pulmonary arterial hypertension. Scand J Rheumatol 47:319-324

14. Säleby J, Bouzina H, Lundgren J, Rådegran G (2017) Angiogenic and inflammatory biomarkers in the differentiation of pulmonary hypertension. Scand Cardiovasc J 51:261-270

15. Fang JC, DeMarco T, Givertz MM, Borlaug BA, Lewis GD, Rame JE, Gomberg-Maitland M, Murali S, Frantz RP, McGlothlin D, Horn EM, Benza RL (2012) World Health Organization Pulmonary Hypertension Group 2: pulmonary hypertension due to left heart disease in the adult - a summary statement from the Pulmonary Hypertension Council of the International Society for Heart and Lung Transplantation. J Heart Lung Transplant 31:913-933

16. Charalampopoulos A, Lewis R, Hickey P, Durrington C, Elliot C, Condliffe R, Sabroe I, Kiely DG (2018) Pathophysiology and diagnosis of pulmonary hypertension due to left heart disease. Frontiers in medicine 5:174

17. Ibrahim NE, Januzzi JL (2017) Beyond natriuretic peptides for diagnosis and management of heart failure. Clin Chem 63:211-222

18. Assarsson E, Lundberg M, Holmquist G, Björkesten J, Bucht Thorsen S, Ekman D, Eriksson A, Rennel Dickens E, Ohlsson S, Edfeldt G, Andersson AC, Lindstedt P, Stenvang J, Gullberg M, Fredriksson S (2014) Homogenous 96-Plex PEA immunoassay exhibiting high sensitivity, specificity, and excellent scalability. PLoS One 9:e95192

19. Nyman U, Grubb A, Larsson A, Hansson LO, Flodin M, Nordin G, Lindström V, Björk J (2014) The revised Lund-Malmö GFR estimating equation outperforms MDRD and CKD-EPI across GFR, age and BMI intervals in a large Swedish population. Clin Chem Lab Med 52:815-824

20. Mehra MR, Kobashigawa J, Starling R, Russell S, Uber PA, Parameshwar J, Mohacsi P, Augustine S, Aaronson K, Barr M (2006) Listing criteria for heart transplantation: international society for heart and lung transplantation guidelines for the care of cardiac transplant candidates-2006. J Heart Lung Transplant 25:1024-1042

21. Mehra MR, Canter CE, Hannan MM, Semigran MJ, Uber PA, Baran DA, Danziger-Isakov L, Kirklin JK, Kirk R, Kushwaha SS, Lund LH, Potena L, Ross HJ, Taylor DO, Verschuuren EAM, Zuckermann A (2016) The 2016 international society for heart lung transplantation listing criteria for heart transplantation: a 10-year update. J Heart Lung Transplant 35:1-23

22. Ahmed A, Ahmed S, Arvidsson M, Bouzina H, Lundgren J, Rådegran G (2019) Prolargin and matrix metalloproteinase-2 in heart failure after heart transplantation and their association with haemodynamics. ESC Heart Failure. https://doi.org/10.1002/ehf2.12560
23. Benjamini Y, Krieger AM, Yekutieli D (2006) Adaptive linear step-up procedures that control the false discovery rate. Biometrika 93:491-507

24. Achen MG, Jeltsch M, Kukk E, Mäkinen T, Vitali A, Wilks AF, Alitalo K, Stacker SA (1998) Vascular endothelial growth factor $\mathrm{D}$ (VEGF-D) is a ligand for the tyrosine kinases VEGF receptor 2 (Flk1) and VEGF receptor 3 (Flt4). Proc Natl Acad Sci USA 95:548-553

25. Bhardwaj S, Roy H, Heikura T, Ylä-Herttuala S (2005) VEGF$\mathrm{A}$, VEGF-D and VEGF-D $\Delta \mathrm{N} \Delta \mathrm{C}$ induced intimal hyperplasia in carotid arteries. Eur J Clin Investig 35:669-676

26. Achen MG, Stacker SA (2012) Vascular endothelial growth factorD: signaling mechanisms, biology, and clinical relevance. Growth Factors 30:283-296

27. Dumont DJ, Jussila L, Taipale J, Lymboussaki A, Mustonen T, Pajusola K, Breitman M, Alitalo K (1998) Cardiovascular failure in mouse embryos deficient in VEGF receptor-3. Science 282:946-949

28. Baluk P, Tammela T, Ator E, Lyubynska N, Achen MG, Hicklin DJ, Jeltsch M, Petrova TV, Pytowski B, Stacker SA, Ylä-Herttuala S, Jackson DG, Alitalo K, McDonald DM (2005) Pathogenesis of persistent lymphatic vessel hyperplasia in chronic airway inflammation. J Clin Investig 115:247-257

29. McCormack FX, Gupta N, Finlay GR, Young LR, Taveira-DaSilva AM, Glasgow CG, Steagall WK, Johnson SR, Sahn SA, Ryu JH, Strange C, Seyama K, Sullivan EJ, Kotloff RM, Downey GP, Chapman JT, Han MK, D'Armiento JM, Inoue Y, Henske EP, Bissler JJ, Colby TV, Kinder BW, Wikenheiser-Brokamp KA, Brown KK, Cordier JF, Meyer C, Cottin V, Brozek JL, Smith K, Wilson KC, Moss J (2016) Official American Thoracic Society/ Japanese Respiratory Society Clinical Practice Guidelines: lymphangioleiomyomatosis diagnosis and management. Am J Respir Crit Care Med 194:748-761

30. Borné Y, Gränsbo K, Nilsson J, Melander O, Orho-Melander M, Smith JG, Engström G (2018) Vascular endothelial growth factor $\mathrm{D}$, pulmonary congestion, and incidence of heart failure. J Am Coll Cardiol 71:580-582

31. Vachiéry JL, Adir Y, Barberà JA, Champion H, Coghlan JG, Cottin V, De Marco T, Galiè N, Ghio S, Gibbs JSR, Martinez F, Semigran M, Simonneau G, Wells A, Seeger W (2013) Pulmonary hypertension due to left heart diseases. J Am Coll Cardiol 62:D100-D108

32. Houston BA, Tedford RJ, Baxley RL, Sykes B, Powers ER, Nielsen CD, Steinberg DH, Maran A, Fernandes VLC, Todoran T, Jones JA, Zile MR (2019) Relation of lymphangiogenic factor vascular endothelial growth factor-D to elevated pulmonary artery wedge pressure. Am J Cardiol 124:756-762

33. Hou J, Kang YJ (2012) Regression of pathological cardiac hypertrophy: signaling pathways and therapeutic targets. Pharmacol Ther 135:337-354

34. Hartikainen J, Hassinen I, Hedman A, Kivelä A, Saraste A, Knuuti J, Husso M, Mussalo H, Hedman M, Rissanen TT, Toivanen P, Heikura T, Witztum JL, Tsimikas S, Ylä-Herttuala S (2017) Adenoviral intramyocardial VEGF-DDeltaNDeltaC gene transfer increases myocardial perfusion reserve in refractory angina patients: a phase I/IIa study with 1-year follow-up. Eur Heart J 38:2547-2555

35. Ghatalia P, Morgan CJ, Je Y, Nguyen PL, Trinh QD, Choueiri TK, Sonpavde G (2015) Congestive heart failure with vascular endothelial growth factor receptor tyrosine kinase inhibitors. Crit Rev Oncol Hematol 94:228-237

36. Fayyaz AU, Edwards WD, Maleszewski JJ, Konik EA, DuBrock HM, Borlaug BA, Frantz RP, Jenkins SM, Redfield MM (2018) Global pulmonary vascular remodeling in pulmonary hypertension associated with heart failure and preserved or reduced ejection fraction. Circulation 137:1796-1810 
37. Al-Husseini A, Kraskauskas D, Mezzaroma E, Nordio A, Farkas D, Drake JI, Abbate A, Felty Q, Voelkel NF (2015) Vascular endothelial growth factor receptor 3 signaling contributes to angioobliterative pulmonary hypertension. Pulm Circ 5:101-116

38. Säleby J, Bouzina H, Ahmed S, Lundgren J, Rådegran G (2019) Plasma receptor tyrosine kinase RET in pulmonary arterial hypertension diagnosis and differentiation. ERJ Open Res 5:00037

39. Tedford RJ, Hassoun PM, Mathai SC, Girgis RE, Russell SD, Thiemann DR, Cingolani OH, Mudd JO, Borlaug BA, Redfield MM, Lederer DJ, Kass DA (2012) Pulmonary capillary wedge pressure augments right ventricular pulsatile loading. Circulation 125:289-297

40. Miller WL, Grill DE, Borlaug BA (2013) Clinical features, hemodynamics, and outcomes of pulmonary hypertension due to chronic heart failure with reduced ejection fraction: pulmonary hypertension and heart failure. JACC Heart Fail 1:290-299

41. Al-Naamani N, Preston IR, Paulus JK, Hill NS, Roberts KE (2015) Pulmonary arterial capacitance is an important predictor of mortality in heart failure with a preserved ejection fraction. JACC Heart Fail 3:467-474

42. Wadugu B, Kühn B (2012) The role of neuregulin/ErbB2/ ErbB4 signaling in the heart with special focus on effects on cardiomyocyte proliferation. Am J Physiol Heart Circ Physiol 302:H2139-H2147

43. Rohrbach S, Niemann B, Silber RE, Holtz J (2005) Neuregulin receptors erbB2 and erbB4 in failing human myocardium. Basic Res Cardiol 100:240-249

44. Heaney ML, Golde DW (1998) Soluble receptors in human disease. J Leukoc Biol 64:135-146

45. Björkbacka H, Yao Mattisson I, Wigren M, Melander O, Fredrikson GN, Bengtsson E, Gonçalves I, Almgren P, Lagerstedt JO, Orho-Melander M, Engström G, Nilsson J (2017) Plasma stem cell factor levels are associated with risk of cardiovascular disease and death. J Intern Med 282:508-521

46. Hjalmarson Å, Goldstein S, Fagerberg B, Wedel H, Waagstein F, Kjekshus J, Wikstrand J, El Allaf D, Vítovec J, Aldershvile J, Halinen M, Dietz R, Neuhaus K-L, Jánosi A, Thorgeirsson G, Dunselman PHJM, Gullestad L, Kuch J, Herlitz J, Rickenbacher P, Ball S, Gottlieb S, Deedwania P, Group ftM-HS (2000) Effects of controlled-release metoprolol on total mortality, hospitalizations, and well-being in patients with heart failure the metoprolol $\mathrm{CR} / \mathrm{XL}$ randomized intervention trial in congestive heart failure (MERIT-HF). JAMA 283:1295-1302

47. López-Sendón J, Swedberg K, McMurray J, Tamargo J, Maggioni AP, Dargie H, Tendera M, Waagstein F, Kjekshus J, Lechat P, Pedersen CT, Members TF (2004) Expert consensus document on angiotensin converting enzyme inhibitors in cardiovascular disease: The Task Force on ACE-inhibitors of the European Society of Cardiology. Eur Heart J 25:1454-1470

48. Ko HT, Yin JL, Wyburn K, Wu H, Eris JM, Hambly BD, Chadban SJ (2012) Sirolimus reduces vasculopathy but exacerbates proteinuria in association with inhibition of VEGF and VEGFR in a rat kidney model of chronic allograft dysfunction. Nephrol Dial Transplant 28:327-336

49. Goldberg HJ, Harari S, Cottin V, Rosas IO, Peters E, Biswal S, Cheng Y, Khindri S, Kovarik JM, Ma S, McCormack FX, Henske EP (2015) Everolimus for the treatment of lymphangioleiomyomatosis: a phase II study. Eur Respir J 46:783

50. Young L, Lee H-S, Inoue Y, Moss J, Singer LG, Strange C, Nakata K, Barker AF, Chapman JT, Brantly ML, Stocks JM, Brown KK, Lynch JP 3rd, Goldberg HJ, Downey GP, Swigris JJ, TaveiraDaSilva AM, Krischer JP, Trapnell BC, McCormack FX, Group MT (2013) Serum VEGF-D a concentration as a biomarker of lymphangioleiomyomatosis severity and treatment response: a prospective analysis of the Multicenter International Lymphangioleiomyomatosis Efficacy of Sirolimus (MILES) trial. Lancet Respir Med 1:445-452

51. Budde K, Zonnenberg BA, Frost M, Cheung W, Urva S, Brechenmacher T, Stein K, Chen D, Kingswood JC, Bissler JJ (2016) Pharmacokinetics and pharmacodynamics of everolimus in patients with renal angiomyolipoma and tuberous sclerosis complex or lymphangioleiomyomatosis. Br J Clin Pharmacol 81:958-970

52. Choe J-Y, Lee S-J, Park S-H, Kim S-K (2012) Tacrolimus (FK506) inhibits interleukin-1 $\beta$-induced angiopoietin-1, Tie-2 receptor, and vascular endothelial growth factor through down-regulation of JNK and p38 pathway in human rheumatoid fibroblast-like synoviocytes. Jt Bone Spine 79:137-143

53. Hugh J, Van Voorhees AS, Nijhawan RI, Bagel J, Lebwohl M, Blauvelt A, Hsu S, Weinberg JM (2014) From the Medical Board of the National Psoriasis Foundation: the risk of cardiovascular disease in individuals with psoriasis and the potential impact of current therapies. J Am Acad Dermatol 70:168-177

54. Aghazadeh S, Yazdanparast R (2016) Mycophenolic acid potentiates HER2-overexpressing SKBR3 breast cancer cell line to induce apoptosis: involvement of AKT/FOXO1 and JAK2/STAT3 pathways. Apoptosis 21:1302-1314

55. Du Bois D, Du Bois EF (1916) Clinical calorimetry: tenth paper a formula to estimate the approximate surface area if height and weight be known. Arch Intern Med 17:863-871

Publisher's Note Springer Nature remains neutral with regard to jurisdictional claims in published maps and institutional affiliations. 